\title{
Entre o Realismo e o Ficcional: Representações sobre "Raça"1, Sexualidade e Classe em Dois Romances Paradigmáticos de Jorge Amado 2
}

LAURA MOUTINHO

Neste artigo é apresentada e discutida a forma como as concepções e representações sobre "raça", miscigenação, sexualidade, gênero, erotismo e casamento são operadas em duas obras paradigmáticas representativas de dois importantes períodos da trajetória de Jorge Amado: Jubiabá, da fase nomeada de "romance proletário", e Gabriela, Cravo e Canela, tido como o livro que representa uma virada na carreira do autor, inaugurando o período do chamado "romance dialógico". Esses dois romances são protagonizados por casais inter-raciais que funcionam como o suporte a partir do qual Jorge Amado veicula algumas representações correntes na sociedade (e na ciência da época), não somente sobre a relação entre negros e brancos, como, igualmente, de uma nação que em um nível se percebe como mestiça e em outro enfrentava (e enfrenta) o dilema da diferenciação racial. Como será visto, desejo proibido e luta de classes vividos pelo par homem negro / mulher branca (Jubiabá), uma vez contrastados com erotismo, casamento e progresso em foco na relação homem (quase) branco / mulher mestiça, lançam luzes sobre algumas das representações de nação presentes e veiculadas na sociedade brasileira por suas mais variadas instituições.

Palavras chave: Raça / miscigenação; sexualidade; classe; representações de nação. 
No Norte, terra da promissão, há uma grande confusão de raças e de sentimentos. É a formação de um povo. E dessa confusão está saindo uma raça doente e indolente AMADO apud ALMEIDA (1979, p. 58 - grifo no original)

\section{Introdução}

As palavras acima são do País do Carnaval, livro de estréia de Jorge Amado, publicado em 1931. Sua afinidade com as percepções sobre miscigenação, dominantes à época, como algo que leva à degenerescência e constitui um problema do ponto de vista da nação, tão eloqüentes em seu primeiro romance, está completamente relativizada em seu quarto livro, Jubiabá, editado apenas três anos depois. Alguns comentadores da obra de Jorge Amado classificam esse período como a fase do "romance proletário"4: Cacau (1933), Suor, (1934) e Jubiabá (1935) (ALMEIDA, 1979).

Roquette Pinto e Gilberto Freyre estão entre aqueles a quem Jorge Amado se aproxima no período em foco, tendo inclusive participado com afinco do I Congresso Afro-Brasileiro organizado por Freyre em Recife, em 1934. Almeida (1979, p. 121-122) argumenta:

“Amado, com Jubiabá, acompanhando Freyre de perto, parece desfazer no seu pensamento a 'confusão de raças' que afirmara em 1931. Incide numa valorização do negro. Exalta seus conhecimentos e religião. O personagem central é concebido como representante de uma cultura específica, que o autor apregoa seja reconhecida como tal. [...] Articula o combate às teorias racistas com a defesa da participação política do proletariado na cena política construída. [...]. Entrelaça o proletário e o negro”.

Apesar da afinidade com Freyre, em Jubiabá a mulata ainda não é a "tal". Um referencial que se modifica completamente com Gabriela, Cravo e Canela, que alguns intérpretes de sua obra (ALMEIDA, 1979; Matta, 1983) demarcam como sendo o ponto de ruptura com o "realismo socialista". Creio, entretanto, que esse deslocamento engendra, concomitantemente, uma mudança em sua concepção acerca das relações entre negros e brancos e da própria idéia de nação presentes na sua obra. Da boêmia, passando pelo círculo de 
"pensadores católicos" (cuja influência pode ser apreendida em $O$ País do Carnaval), pela militância em movimentos políticos de esquerda (com Jubiabá), até a ruptura (cujo símbolo é Gabriela...) vemos como o autor acaba por se legitimar como acadêmico, com cadeira na Academia Brasileira de Letras e vínculos, como demonstrou Almeida, com o Estado, através dos "conselhos de cultura".

Na percepção de Matta (1983, p. 14), a primeira fase é marcada por uma construção "monológica", com ênfase no registro marxista e em uma "dualidade moral" calcada na oposição entre estruturas feudais arcaicas e burguesas modernizadoras: "neles pode-se aplicar perfeitamente o modelo de Bakhtin, dizendo que são obras onde o autor fala do herói (ou heróis)". Quando Gabriela ocupa o centro da cena, Amado inicia uma construção "dialógica" na qual "o autor não fala do herói mas com o herói" (BAKHTIN apud MATTA, 1983, p. 13). Na interpretação de Matta e de vários outros autores, esse é o momento em que Jorge Amado não opera mais com um olhar engessado por teorias explicativas sobre como o mundo deve ser. Antes, "assume uma posição empírica diante das coisas. Deixa de ditar normas e decide captar sentido, significado e valores por meio dos seus personagens" (MATTA, 1983, p. 16 - grifos meus).

Se, por um lado, Jubiabá enceta uma valorização dos negros e da sua cultura; por outro, o compromisso com uma vertente socialista comprometeria, segundo seus críticos, sua autenticidade. A guinada que esse corte político representa com Gabriela, Cravo e Canela, no sentido de aproximá-lo mais de uma "posição empírica", na curiosa expressão de Matta, teve repercussões interessantes: "Gabriela [...] converte-se para os políticos num reflexo de reivindicações populares, às quais se apressam em atender", diz Almeida (1979, p. 256). Como fica explícito no seguinte telegrama que Jorge Amado recebeu:

"Não podia deixar de pedir ao prezado amigo o favor de comunicar oficialmente a Gabriela já haver sido aberta a concorrência para a construção do porto de Ilhéus. Cordiais saudações. Ernani do Amaral Peixoto, Ministro da Viação e obras públicas” (apud ALMEIDA, 1979, p. 257).

Com Gabriela, Cravo e Canela, Jorge Amado ingressa e se legitima no establishment acadêmico e estatal. Significativamente, é através dessa obra e personagem - inesquecível na televisão na pele de Sônia Braga - que temos uma aproximação narrativa de Jorge Amado com Gilberto Freyre, ainda que, 
na distante década de 30, autor já influenciasse a concepção de "raça" daquele.

Nesse sentido, a literatura está, aqui, sendo compreendida tal como a concebe Edward Said (1995), como uma forma cultural que fornece "estruturas de atitude e experiências". Em resumo, uma forma cultural que veicula mas igualmente forma sentimentos e experiências. Muito do que veremos nas próximas páginas ocupa desde nossos livros escolares, passando pelos discursos políticos até os acadêmicos, a despeito das múltiplas identidades disciplinares. Süssekind (1984) segue nessa direção quando destaca a forte tendência presente na literatura brasileira de enfatizar o contexto "extralitérário". Trata-se de uma literatura que se pretende, em inúmeros casos, períodos e "escolas", ser um sismógrafo da "realidade".

Assim, na análise subseqüente, apresento e discuto a forma como as concepções e representações sobre "raça", miscigenação, gênero, erotismo e casamento são operadas em duas obras paradigmáticas representativas de dois períodos da trajetória de Jorge Amado: Jubiabá, da fase nomeada de "romance proletário", e Gabriela, Cravo e Canela, tido como o livro que inaugura um outro registro, o do "romance dialógico". Significativamente, esses livros são protagonizados por relacionamentos afetivos-sexuais "inter-raciais": o primeiro trata do amor impossível entre o "negro pobre" Antônio Balduíno e a "branca rica e loira" Lindnalva; o segundo conta a história de amor da "mulata" Gabriela e do "árabe" Nacib. Naquele o homem é o principal protagonista, neste, é a mulher. Passemos à análise das obras.

\section{Jubiabá}

Esse livro, ao contrário de outros escritos por Jorge Amado, envolve o leitor com uma narrativa melancólica e lúgubre. Ao longo de suas trezentas e poucas páginas, o autor descreve as amarguras dos pobres e humildes de Salvador, Bahia. O tom é de desesperança. Entre uma ida ou outra de Antônio Balduíno, o protagonista, à macumba de pai Jubiabá, à Lanterna dos Afogados, para tocar umas "modas", beber cachaça e "bolir" com as "mulatas", vemos um cenário de fome, injustiça social, pobreza, abandono, mortes e suicídio.

Àquelas pessoas nada restava senão acreditar no destino. A falta de opções e alternativas, a inescapável pobreza, somente rendem aos personagens uma crença de que tudo está nas mãos do destino. A situação de desigualdade social desenhada no livro mostra, justamente, que aqueles homens e mulheres 
Entre o Realismo e o Ficcional: Representações sobre "Raça"...

"negros" e pobres não possuem qualquer controle sobre suas próprias vidas.

\subsection{O "negro" Balduíno e a "branca" Lindnalva: desejo proibido e luta de classes}

O personagem central é o "negro", pobre e órfão Antônio Balduíno, de apelido Baldo. A tia que o criava enlouquece, o moleque Baldo, então, sai do Morro Capa-Negro, onde vivia, e é entregue aos cuidados de uma rica família. Ao longo do livro, seja nas palavras de Antônio Bulduíno, seja de outros personagens, o conflito "racial" é aberto e, freqüentemente lembrado, embora a situação de pobreza e um certo discurso mais classista, por vezes, o amenize. Voltarei a este ponto, que me parece central na narrativa. Por ora voltemos à história.

Balduíno chegou à hora do almoço no rico sobrado do comendador português Pereira, e logo notou Lindnalva. Apesar do nome denotar brancura e beleza, a moça foi descrita como "magríssima e sardenta, os cabelos vermelhos e a boca pequena, fazia o contraste mais ridículo do mundo" (AMADO, 1995, p. 44), exsudando, entretanto, um ar de santa.

O contato com a menina e a clara simpatia do comendador pelo menino, aliados às traquinagens infantis e às idas ao cinema, fizeram deste um período quase feliz. O maior problema era o ciúme que a governanta portuguesa nutria contra Baldo. Como o rapaz já sabia ler, o comendador resolveu dar-lhe um emprego em seu armazém. Algo que deixou Amélia, a governanta, tomada de ódio: "não podia compreender por que os patrões protegiam aquele 'negro' e queriam fazer dele gente" (AMADO, 1995, p. 51).

Curiosamente, mas não por acaso, o meio que ela encontrou para desmoralizar Baldo foi afirmar que ele estaria "olhando as coxas de D. Lindnalva". Acrescentando, à mentira, uma outra: "Esse 'negro' é safado que faz medo. Quando dona Lindnalva ia tomar banho ele espiava pelo buraco da fechadura..." (AMADO, 1995, p. 51). A menina, diante da primeira afirmação, passou a olhá-lo com "medo e nojo", e diante da segunda "saiu quase chorando". Resultado: o rapaz leva uma surra "medonha" do comendador e foge com o corpo e o "coração" doídos "porque não tinham acreditado nele. E como aqueles eram os únicos brancos que ele estimava passou a odiá-los e com eles a todos os outros" (AMADO, 1995, p. 51). 
Significativamente, foi o episódio que, mesmo sendo um blefe, despertou o desejo do rapaz:

“[...] nessa noite sonhou com Lindnalva. Ele a viu nua e acordou. E então se lembrou dos vícios que os moleques do morro praticavam [...]. Dormiu com Lindnalva que sorria para ele com seu rosto de figura de folhinha, e para ele abria as coxas alvas e lhe ofertava os seios duros de criança. Virou homem nessa noite. E daí por diante, dormisse com que mulher dormisse, era com Lindnalva que o 'negro' Antônio Balduíno estava dormindo" (AMADO, 1995, p. 51-52).

Para o comendador português, a pureza da menina "branca" estava mantida; para Baldo, estava acesa a ardente chama do desejo. Algo que, saberemos mais tarde, também acomete Lindnalva. Magoado e humilhado, o rapaz foge e se torna líder de uma gangue de pivetes em Salvador. Os amantes se afastam sem nunca terem se tocado. Mas não podem se livrar das lembranças boas dos tempos de meninice, nem do amor e desejo que nutrem um pelo outro.

Baldo vai levando uma típica vida de malandro. Errante, torna-se boxeador, artista de circo, rouba, é preso, apanha mas sai logo da prisão. A Lindnalva é reservado o destino típico de moça "de sociedade": fica noiva de um rapaz também oriundo de família tradicional. Porém, com a mãe já morta, o patriarca se enreda na prostituição que vai aos poucos minando seu patrimônio. Hipoteca a casa, conta com a ajuda do futuro genro para saldar as dívidas. Mudam-se do sobrado para uma casa distante. Até que o comendador falece no prostíbulo.

Com o escândalo, Lindnalva, semanas depois do enterro vazio - além da moça e da governanta, somente compareceram alguns dos amigos do prostíbulo - perde o noivo, que a abandona grávida. Daí em diante, é Lindnalva quem assume uma vida errante. Torna-se prostituta do bordel que o pai freqüentava, envelhece, torna-se alcoólatra, passa para a baixa prostituição, adoece.

A antiga governanta avisa Balduíno que a moça "está na vida": Lindnalva agora atende pelo nome de Linda, não mais alva, deixou de ser pura... Reencontra Baldo, mas não o reconhece. O rapaz foge estupefato e quando, dias depois, já recuperado, volta à morada da amada para se vingar, para "possuíla" e insultá-la, jogando-lhe o dinheiro na cara, a encontra morrendo. Baldo percebe nesse momento que a morte da amada o lançará na solidão, que sua 
morte acabará com sua própria razão de viver. Como dito, tivera e amara Lindnalva em todas as mulheres com quem dormiu. Na hora da morte, Lindnalva pede a Baldo que ajude a governanta a criar seu filho. O rapaz enlouquece:

\footnotetext{
"Ela era virgem, gente... eu juro que era... Ninguém teve ela... Ela não foi de ninguém... Vivia disso mas não se dava... Só eu é que tive ela... Só eu, gente... Quando eu andava com uma mulher tava com a cabeça nela... quero um caixão branco para ela..." (AMADO, 1995, p. 273).
}

Antônio Balduíno consegue seu primeiro emprego (na estiva) para poder criar o filho "branco" de Lindnalva: "Ia ter profissão, ia ser escravo da hora, dos capatazes, dos guindastes e dos navios" (AMADO, 1995, p. 274). E se não fosse o último pedido de Lindnalva, ele entraria pelo mar, se mataria. Mas Baldo possuía uma tarefa a cumprir.

$\mathrm{Na}$ estiva, Baldo se articula aos poucos com o movimento grevista, cuja luta acaba por ter para ele um sentido de revelação. Através das histórias que pai Jubiabá contava sobre Zumbi do Palmares e da infância no morro, ele adquirira o "sentido de raça e de raça oprimida" (AMADO, 1995, p. 50), mas com a adesão ao movimento grevista, que o amor por Lindnalva e o compromisso de criar seu filho "branco" o levaram a assumir, incorporara o sentido de classe. Como disse um "negro" do movimento: "a gente é negro, eles são brancos, mas nesta hora tudo é pobre com fome..." (AMADO, 1995, p. 279).

A partir dessa experiência, Balduíno vai sentindo que, apesar de pobres e oprimidos, eles possuem força, quando há coesão. É essa sensação de poder, o poder dos fracos, que Balduíno aprende: com a greve "não havia luz, nem bondes, nem telefone" (AMADO, 1995, p. 280). Algo que fornece outro sentido às relações com os "brancos": "negro e "branco" pobre, tudo é escravo mas tem tudo na mão. É só não querer, não é mais escravo”, diz, agora, o próprio Balduíno $^{5}$ (AMADO, 1995, p. 287).

A sua luta é por ele, pelos "brancos" e "negros" pobres, mas também para que seu filho "branco" não seja, no futuro, "um escravo". Antônio Balduíno descobre algo que nem pai Jubiabá sabia, que a greve é uma arma contra a escravidão. Para ele, Zumbi - aquele que morreu para não ser escravo - sabia de todas aquelas coisas, que ele somente "agora" havia aprendido. Com a greve "aprendeu a amar todos os mulatos, todos os negros, todos os brancos [...] que são escravos que estão rebentando as cadeias" (AMADO, 1995, p. $321)$. 
O amor do "negro" e pobre Antônio Balduíno e da "branca" e rica Lindnalva... Um amor impossível. Mas se o homem "branco" e dominador (rico) com a mulher "mestiça" e pobre fazem a nação, ao homem "negro" com a mulher "branca" cabem fazer a revolução social: "cor", classe e gênero justapostos impediram tal relacionamento. Algo, talvez, somente possível através da mudança da estrutura de classe existente.

Seguindo o percurso do amor e do desejo, Jorge Amado alinhava o caminho da revolução social. Um amor heterogâmico em todos os sentidos envolve diferenças de "cor", classe e educação - funciona como argumento central da desconstrução das relações de classe. Baldo se tornara estivador para ajudar a antiga governanta a criar o filho de Lindnalva. Vai para a estiva por amor, um amor nunca realizado. Mas o interessante é que o sentimento que Gustavinho, o filho "branco" bastardo, nele desperta, é um sentimento de coletividade e de classe.

O livro termina com uma celebração festiva entre as "raças", conferindo um novo sentido a essa relação. Zumbi, que sabia das coisas, ensinara Balduíno a não ser escravo, mas o desenrolar da história sugere algo mais: um sentido conciliatório à relação entre as três "raças", quando percebidas do ponto de vista da exclusão e da opressão. Zumbi aparece assim (re)atualizado e (res)significado no interior da luta de classe: fornece um sentido "racializado" ao engajamento político, que opera - pela lógica da opressão - um concomitante plano conciliatório. Parece que o triângulo hierarquizante e conciliador, analisado por Matta (1981), desfaz-se. As três "raças" continuam presentes; contudo, ao serem percebidas pela lógica da desigualdade de classe e das relações de produção, ressalta-se sua igualdade e não-diferenciação no plano social. Balduíno, como mediador entre as "raças", luta para que o "filho branco" não seja escravo. Uma criança cujo pai - o advogado Gustavo Barreiras - havia traído os grevistas, aceitando um cargo na companhia empregadora.

Se o par homem "negro" / mulher "branca" desvela irredutíveis diferenças de classe, funciona, igualmente, na fase do "romance proletário" de Jorge Amado, como o mote da revolução social. A luta de classes articula metonimicamente os significantes "cor" e desejo. A greve é como "um colar", dizem os personagens: se alguém romper uma conta o elo se desfaz. A metáfora do colar é, igualmente, útil na ligação entre amor e desejo na rearticulação e ressiginificação das diferenças "raciais". Estas são possíveis porque foi através do engajamento político que Antônio Balduíno pôde ver a si mesmo, e aos pobres 
"brancos" e "negros", com grandeza e dignidade. Nesse sentido, é curioso acompanhar como se modifica seu código de honra. Antes dessa experiência reveladora, tudo o que o personagem possuía era a sua honra masculina construída com base na valentia, na esperteza e na relação com as "mulatas". Esse era o fator diferencial de status para aqueles que nada possuíam para ostentar para os demais. A partir da experiência com a greve, ocorre um deslocamento: a base individualista anterior adquire um sentido de coletividade, de modo que a força e a valentia, por exemplo, deveriam ser controladas, e somente utilizadas em prol da greve. Do mesmo modo, modifica-se a percepção de si que o personagem possuía. Um sentido de grandeza é agora experimentado de forma consistente.

$\mathrm{O}$ aspecto mais interessante nisso tudo se refere à força dos afetos e desejos "inter-raciais" na dramatização dos conflitos presentes na sociedade brasileira. De fato, valores distintos são atribuídos aos pares "inter-raciais". Entretanto, seja para celebrar ou depreciar a nação, seja para expor seus conflitos sob a ótica da desigualdade de classe, o foco é sempre ajustado em direção aos relacionamentos afetivo-sexuais "inter-raciais". Cabe, porém, ressaltar: o amor, desejo ou contato do par homem "negro" / mulher "branca" são irrealizáveis. Trata-se, de qualquer forma, de um contato tabu. Tanto que o filho que Balduíno toma para si é, de fato, filho de um homem "branco" com uma mulher igualmente "branca". O amor de Balduíno pela moça produziu no "negro" um ponto de contato com os "brancos", mas não deixou de ser um amor impossível e irrealizável. Ainda que Lindnalva tenha se tornado somente Linda e que o resultado da greve tenha sido um sucesso.

Como demonstrou Stolcke (1991), uma característica básica da sociedade de classes é a naturalização e biologização das desigualdades sociais. Nessa perspectiva, as diferenças de sexo e "raça" são fontes fundamentais de atribuição diferenciada de poder e prestígio. Algo que vem a operar um elo entre a idéia de igualdade de oportunidades para todos os indivíduos e, concomitantemente, justificar a desigualdade e a ausência de acesso a essas oportunidades, com base em seus "dotes" biológicos.

Trata-se de um tipo de estratégia que leva a uma ressignificação dos laços de descendência como atribuição de status, agora operantes na sociedade de classes. Seguindo essa chave interpretativa, vamos nos deparar com a importância da endogamia na manutenção e reprodução dos privilégios de classe. Como corolário, a mulher acaba por ocupar um lugar central, pois é no controle 
de sua sexualidade (pelos homens) que a reprodução endogâmica se perpetua. Nessa seqüência, a idéia de fragilidade feminina emerge em oposição à sua força e importância para a reprodução social, pois é através do binômio fragilidade-proteção que os homens legitimam seu papel, de modo a controlar a sexualidade feminina (STOLCKE, 1991).

Mas tais considerações adquirem, em um país "mestiço" como o Brasil, colorações interessantes. A questão pode ser formulada da seguinte maneira: como manter os privilégios de poder e prestígio e, concomitantemente, valorizar a miscigenação como uma forma de branqueamento da nação? Creio que é nesse ponto que a desigualdade de gênero, em especial a dominação masculina, articula-se à cor, classe e erotismo de modo específico em nossa sociedade. Uma idéia que poderá ser mais desenvolvida a partir da análise do romance de Jorge Amado, Gabriela, Cravo e Canela.

\section{Gabriela, Cravo e Canela}

O livro de Jorge Amado conta a história de amor da "mulata" Gabriela e do "árabe" Nacib. A "cor" do casal segue uma espécie de linha cromática recorrente no texto, que desenha e colore os outros casais que vivem no livro suas aventuras afetivo-sexuais. Jorge Amado narra, de fato, histórias de homens "brancos" com suas esposas e amantes. Os homens "negros" ou "mulatos" não aparecem na história com vida afetivo-sexual; quando muito é possível encontrá-los (especialmente os "negros") no âmbito do mundo do trabalho, mas nunca, reitero, dos afetos. As mulheres "brancas" parecem ser aquelas a quem se reserva o casamento, embora haja prostitutas "brancas". É às raparigas, em geral "mulatas" e eventualmente "negras", que cabe o papel de amantes, "amigas" ou prostitutas. Os coronéis somente montam casa e abrem conta nas lojas para as "não-brancas": as "raparigas de cama e mesa [...] mulatinhas no verdor dos anos" (AMADO, 1958, p. 139).

Costura a narrativa um crime passional. Sua importância fica evidente no destaque que o assassinato recebe logo no primeiro parágrafo do romance. $\mathrm{O}$ ponto de contato inicial é cronológico. $\mathrm{O}$ árabe Nacib vê-se sem sua antiga cozinheira - o que o leva a encontrar Gabriela - no mesmo dia em que o fazendeiro Jesuíno Mendonça assassina a tiros sua esposa, Dona Sinhazinha Guedes de Mendonça, e o dentista local, Osmundo Pimentel, pegos em flagrante adultério. Mas na estrutura lógica do texto, o crime passional fornece os 
ingredientes necessários para a caracterização dos conflitos relativos à modernização de Ilhéus. As hierarquias de gênero, sexo, erotismo são a argamassa da oposição tradição versus modernidade; Estado e justiça formalmente organizadas versus poder local e coronelismo, pautados em uma específica idéia de honra masculina. O adultério, cujo resultado foi a "honra lavada a sangue", ressalta, por oposição, a alternativa à traição feminina concebida por Nacib nas páginas finais do livro. O árabe imbuído de espírito civilizatório acabara por substituir a valentia pela sabedoria. Mas estou me adiantando; antes de mencionar esse aspecto é preciso retomar o fio da história.

Para organizar a análise, parece-me útil operar com a distinção proposta por Strozenberg (1983), relativa aos dois diferentes níveis que estruturam a narrativa de Jorge Amado neste escrito: um referido ao compromisso com o real - que se atém à chegada do progresso em Ilhéus; e o outro, que focaliza a mudança nos costumes através da história de Gabriela e, acrescentaria, de seu idílio amoroso com o "árabe".

\subsection{O "árabe" Nacib e a "morena" Gabriela: desejo, progresso e a marca colonizadora}

Gabriela atravessara a caatinga, no caminho para Ilhéus, fugindo da seca e "deitando-se" toda noite com Clemente, de quem o autor somente informa que deseja enriquecer com roças de cacau. Aqui e ali, Gabriela vai sendo descrita como uma mulher irresistível - "olhos ora tímidos e cândidos, ora insolentes e provocadores", seus "passos de dança", "olhos de inocência" (AMADO, 1958, p. 112-113), sorriso que "tonteia" -, que "se entregava, toda abandonada nas mãos" de Clemente à noite, mas que o tratava como igual aos outros a partir do amanhecer. Quanto aos seus planos de casamento e apesar do ar desprotegido, Gabriela limitava-se a rir, maneando a cabeça e dizendo: "vou pro mato, não". Clemente ficara sem tê-la, apaixonado, confuso e, sobretudo, embriagado. Embriagado por sua beleza e sedução, confuso por sua liberdade, por sua fruição relativa ao sexo ${ }^{6}$.

Nacib, em busca de uma cozinheira, encontra Gabriela no "mercado de escravos". A sujeira da retirante não permite que Nacib vislumbre, inicialmente, seu encanto. Mas aos poucos, a "morena cor de canela" vai mostrando seus encantos femininos, atiçando o desejo do árabe com seu perfume de cravo e sua sensualidade. Logo, portanto, a parceria de cama e mesa se estabelece 
entre os dois ${ }^{7}$. O talento de Grabiela na cozinha aliado às suas visitas ao bar incrementam os negócios de Nacib: "exclamações ressoavam à sua entrada: aquele passo de dança, os olhos baixos, o sorriso espalhando-se dos seus lábios para todas as bocas" (AMADO, 1958, p. 200) - estava, assim, deflagrado o inferno pessoal do árabe.

Apesar de sentir o amor e o desejo de Gabriela, das noites ardentes a "morrer e nascer" em seus braços, passou a viver o inferno do ciúme: perdera a serenidade. Perpassa grande parte do livro a angústia de Nacib relativa ao incessante cerco que Gabriela sofria de todos os homens. Uns querendo montar casa, transformá-la em rapariga, outros a cortejando só e simplesmente para uma noite de amor. Suas negativas às propostas não eram suficientes para amenizar o medo de Nacib de perdê-la.

O casamento, como solução aventada, trouxe novas dúvidas: o que pensariam as pessoas se ele se casasse com uma mulata - quando se referia ao casamento a moça passava de "cor de canela" e "cheiro de cravo", a "mulata" - sem registro de nascimento nem sobrenome, sem virgindade... Tratava-se de um "casamento acima das convenções sociais, das diferenças de posição e classe" (AMADO, 1958, p. 298). Uma percepção, aliás, que era partilhada por Gabriela, que não se considerava uma moça própria para casar com o árabe: "[...] Valia a pena não... Seu Nacib era para casar com moça distinta, toda nos 'brinques', calçando sapato, meia de sêda, usando perfume. Moça donzela, sem vício de homem. Gabriela servia para cozinhar [...], com homem deitar. Não velho e feio, não por dinheiro. Por gostar de deitar", refletia a "morena". Um casamento que veio, entretanto, a se realizar.

Uma vez Senhora Saad, Nacib inicia um processo civilizatório em Gabriela, cuja tortura pode ser sintetizada no horror da moça em ser obrigada a usar sapatos: símbolo de sua nova posição social. Como uma senhora de "posses, de representação", ocupando agora o lugar de esposa, a moça deveria se enquadrar às exigências e obrigações que tal papel lhe reservava.

O árabe seguia sem a angústia de antes, tratando, sobretudo, da transformação da retirante em uma senhora da sociedade. Mas Gabriela, por sua vez, ia perdendo a alegria. Tudo que amava fazer era-lhe agora proibido, sentia-se reprimida, mas cedia. Não desejava magoar o "moço bonito". Resultado: obedecia a Nacib e fazia o que desejava escondido dele. Com isso, o amor "exigente e lascivo" se acalmara. Vivia agora com o árabe o doce amor de esposa. 
O romance parece sugerir que à mulher, a despeito da "cor" e da classe, era reservado no casamento o lugar da deserotização. Algo somente possível, de fato, para homens e mulheres fora do enquadramento ao qual todos eram submetidos com o matrimônio. O melhor retrato do casamento sob a ótica feminina é resumido, no livro, nas reflexões da "moderna" Malvina. Menina rica, filha de fazendeiro, não deseja casamento arranjado, pois isto significa prisão. Seus pais the fornecem o modelo:

"[...] sua festa era a Igreja [referia-se à mãe]. [...] A mãe cuidando da casa, seu único direito. O pai nos cabarés, nas casas de mulheres, gastando com raparigas, jogando nos hotéis, nos bares, com os amigos bebendo. A mãe a fenecer em casa, a ouvir e obedecer. Macilenta e humilhada [...]" (AMADO, 1958, p. 277).

Mas o problema do casamento não era apenas dele ser "arranjado" com o filho de um fazendeiro ou não. $\mathrm{O}$ amor e mesmo o casamento com um "doutor" - "sem a mentalidade atrasada" dos fazendeiros - igualmente representavam uma prisão. A rebeldia do amor é, desse modo, também enquadrada pela instituição casamento. O resultado? Perda da alegria feminina, a proibição da maquiagem, os domingos reservados à Igreja e o inevitável ciclo de parir e cuidar de filhos. Era esse o "destino das mulheres de Ilhéus" (AMADO, 1958, p. 279).

Malvina e Gabriela são as personagens femininas que possuem a chancela da transgressão das normas e valores referidos às mulheres na estrutura social local. Nenhuma das duas se enquadra completamente nos papéis femininos disponíveis; representam simbolicamente ícones opostos, porém em certa medida complementares. A moderna e feminista Malvina rompe completamente com a sociedade local, foge do colégio de freiras de Salvador para onde havia sido enviada, vai para São Paulo trabalhar: casamento e independência se opõem em sua narrativa. Gabriela, ainda que rejeite os costumes locais relativos ao casamento e às raparigas, funciona, na verdade, como mediadora não somente entre nações, através da relação com Nacib, mas igualmente entre classes, como no momento em que larga a festa dos ricos (e os sapatos) e vai para a rua dançar com os pobres. Um ato inusitado que acaba por contaminar os demais convidados, que se juntam à moça na farra de rua, compondo um verdadeiro congraçamento de classe, "cores" e nações.

Algo que pode ser lido pela chave interpretativa proposta por Matta 
(1983, entre outros trabalhos) na qual a festa operaria um tipo de totalização: no "país das festividades, [...] a festa é um dos mecanismos mais importantes para relacionar [...] domínios segregados e afastados uns dos outros" (MATTA, 1983 , p. 10). No caso de Gabriela, entretanto, o congraçamento não estava circunscrito ao calendário civil oficial, mas à espontaneidade. Como mais um ato mediador de um dos elos fundadores da nação - o "mestiço" e feminino irrompe, pelas mãos da personagem, um momento de communitas.

Gabriela seduzira a todos, por sua sensualidade, beleza e simpatia. A alteridade - e a ambigüidade que a caracteriza - não emerge como ameaçadora, antes seduz com cheiro de cravo e "cor" de canela. O operador do congraçamento é o desejo "inter-racial", que surge da espontaneidade e alheio ao casamento e às trocas matrimoniais, que envolvem a transmissão de bens e posição social.

A percepção feminina sobre casamento (e amor), mencionada anteriormente, é partilhada, igualmente, pelos homens. Em certo momento da trama, o "coronel" Altino Brandão - representante do antigo poder local tentava convencer Mundinho Falcão - político local e símbolo da burguesia modernizadora - a se casar. Este, resistente às palavras do "coronel", afirma que "casamento nasce do amor" ou "da necessidade". Ressalta a importância da mulher como companhia, para conversar, "para deitar" e até mesmo na política: "dá filho pra gente, impõe respeito. Pro resto, tem raparigas..." (AMADO, 1958, p. 223). Essa fala ressalta a importância política da mulher (e do parentesco), enquanto moeda de troca nas disputas políticas locais, assim como a percepção diferenciada do casamento para duas classes opostas: a tradicional e a moderna.

Mas, concomitantemente, a mesma mulher que dignifica pode, de acordo com sua postura, desonrar e acabar com a vida de um homem. Na narrativa em questão, é entre as personagens bíblicas Eva e Maria que as mulheres são enquadradas: ou santa ou serpente, ou no lar - "fortaleza da mulher virtuosa" cuidando dos filhos, do esposo, da família, ou "tentação, o diabo, vira a cabeça da gente" (AMADO, 1958, p. 135).

Os calorosos debates em torno do crime passional evidenciavam, justamente, tais representações e serviram de pedra de toque para a atitude de Nacib diante do adultério de Gabriela com seu padrinho de casamento. $O$ árabe, embora tenha planejado matar a mulher e o amante, restringiu-se a distribuir bolachas nos dois, especialmente na "morena". Gabriela chorava enquanto 
apanhava, mas dava razão ao seu homem. Afinal, a culpa era dela: "Por que havia aceitado casar?". Em nenhum momento a moça questiona o adultério em si, mas o fato dela ter "deitado" com outro homem enquanto casada. Isto, sim, era um problema, pois casamento envolve certas leis, às quais ela não conseguira se enquadrar.

Nacib consegue a anulação do casamento após o adultério, descaracterizando, assim, a traição. Não havia motivo para limpar sua "honra com sangue", se Gabriela não era de fato sua esposa - que, aliás, aceitou com satisfação a dissolução do casamento do qual saíra sem qualquer direito. A solução é festejada por todos como um gesto de grande esperteza e sabedoria. Algo digno dos ares de modernidade que estavam envolvendo Ilhéus e oposto à mentalidade atrasada dos fazendeiros locais.

O relacionamento afetivo-sexual do árabe Nacib e da "morena / mulata" Gabriela demarca, de fato, a passagem do "patriarcalismo poligâmico" a um outro modelo de honra e família, que retém, entretanto, a essência civilizatória e hierarquizante do clássico casal colonizador. No final do livro, Nacib saboreia o novo status adquirido: mantivera sua honra masculina de um modo novo e inusitado, ganhara o respeito e admiração locais, mantivera seu negócio de cama e mesa com Gabriela, e podia, ainda, desfrutar os prazeres que as loiras e indígenas do Bataclam podiam proporcionar.

Ao longo da narrativa, vemos ser atualizado o papel que nos clássicos da historiografia era atribuído aos portugueses: estrangeiro, algo mestiço e colonizador com espírito civilizatório. Se incluirmos gênero, sexo e erotismo na fábula conciliadora e hierarquizante de Matta (1981), veremos que o triângulo feminilizado das três "raças" traz a "mulata" (Grabriela) no ápice, como um negócio de cama e mesa, e na base as "raparigas", "brancas" e indígenas (ver figura abaixo). Exterior às trocas matrimonias, o triângulo feminilizado focaliza o desejo e o erotismo que, uma vez "racializado", elege a "mulata / morena" como seu símbolo máximo.

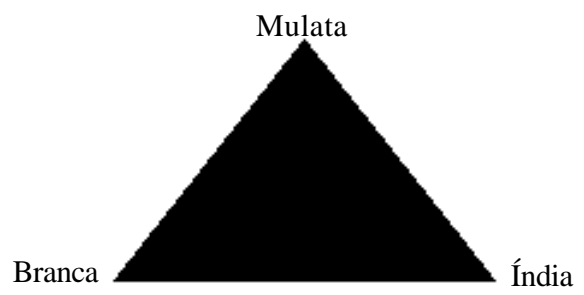


Do ponto de vista da nação - mesmo em sua versão modernizada -, a "mulata" se sobrepõe às "brancas" e indígenas na preferência (no desejo) do quase "branco" colonizador. Tal qual destacou Norvell (2001) nos clássicos, o (homem) "branco" brasileiro possui uma linha de continuidade com o "branco" estrangeiro, criando algo como um continuum, que demarca a especificidade já assinalada por Matta, no sentido de que o "branco" no Brasil, diferentemente dos "arianos", possui "algo tipicamente brasileiro, singular e forte" (MATTA, 1981, p. 76). Assim é Nacib, assim eram os portugueses, assim devemos olhar para os homens "brancos" brasileiros - esta parece ser uma das mensagens que o livro transmite.

Entre os homens "quase brancos" colonizadores e os seus descendentes brasileiros não há uma linha de ruptura. Os colonizadores e os colonizados parecem operar uma dinâmica de semelhança e hierarquia sintetizada na idéia dumontiana (DUMONT, 1992) de "englobamento dos contrários". Se em um nível essas categorias se diferenciam em posições opostas e hierarquicamente separadas, dadas pela própria estrutura de dominação da máquina colonial, em outro nível, quando referidos ao Brasil enquanto nação independente (quando referidos a essa totalidade) os homens "brancos", colonizador e colonizados, vêem-se indiferenciados, compondo o protótipo do espécime masculino fundador da nação. Tanto em $O$ Cortiço, de Aluízio Azevedo, quanto em Gabriela..., por exemplo, os estrangeiros colonizadores se abrasileiram ${ }^{8}$ e os brasileiros, por sua vez, adquirem, nesse englobamento, algo dos colonizadores, estrangeirizam-se, ganham, talvez, algo de civilidade.

Como defende Dumont (1992, p. 373), no diálogo com o clássico artigo de Rorbert Hertz, a relação hierárquica, ao contrário da distintiva, "inclui uma dimensão do valor", valores que se diferenciam em relação ao todo ao qual estão referidos. Deste modo, o "valor relativo" desse casal vai depender da concepção de "raça" e mestiçagem que o presidir. Em $O$ Cortiço, o português Jerônimo, uma vez abrasileirado pela "mulata" Rita Baiana, cai em desgraça e com ele, suponho, a própria nação. Em Gabriela, Cravo e Canela, o "árabe" Nacib, fornece, a partir de elementos similares ao da história anterior, uma saída civilizatória para a honra e a modernização.

Em Gabriela, Cravo e Canela, vemos uma (re)atualização de nosso mito de origem freyreano, tal como desenhado e popularizado pelo autor em Casa-Grande \& Senzala; em $O$ Cortiço, aquele construído pela pena de Paulo Prado, no clássico Retratos do Brasil. Em ambas as obras, porém, vemos 
que a relação entre colonizador e colonizado, quando percebida através do vetor "branco" e masculino, opera uma relação metonímica. Somente esse personagem é capaz de domesticar a alteridade "racial" feminina e construir a "boa nação".

Deste ponto de vista, o tom da "mistura" (sempre hierarquizada), que se justapõe ao tom da nação, será produtor da "boa ordem" se vindo do casal "branco" / mestiça. Trata-se do domínio do macho sobre a fêmea, do "branco" sobre o "não-branco", do colonizador sobre o colonizado, do civilizado sobre o selvagem. O mesmo não ocorre quando se inverte tal composição.

Trata-se da fábula das três raças (feminina) orquestrada pelo estrangeiro "branco" colonizador (homem), que sobrevive e se atualiza aos tempos modernos. Creio que não é à toa que o livro termina com a ("histórica") condenação do coronel assassino: a justiça e o Estado moderno sobrepujando o poder local. Porém, se no plano das representações a lógica masculina da "defesa da honra" foi superada pela esperteza do estrangeiro quase "branco", nos embates cotidianos, cerca de duas décadas depois de o livro ter sido escrito, um personagem, agora das páginas policiais dos jornais - Doca Street - foi absolvido de um crime passional, justamente com o argumento de que este havia sido realizado em "legítima defesa da honra": a "bela morena de Búzios" - Angela Diniz - não teve a mesma sorte de Gabriela.

$\mathrm{Na}$ literatura que analisa a obra e a trajetória de Jorge Amado, vemos, como dito, a demarcação de dois momentos: a fase do "romance proletário" (que inclui Jubiabá) e do "romance dialógico" (iniciada com Gabriela, Cravo e Canela). Chamou-me a atenção o fato de que a fase em que Jorge Amado se mantinha em contato com o marxismo e o socialismo e se opunha ao establishment é aquela em que, de acordo com a interpretação que alguns autores fornecem, o autor tenciona "retratar" de forma tão fiel quanto possível as amarguras de seu povo. No período em que possuía um "compromisso com a verdade", "retrata", curiosamente, a vida dos oprimidos através da relação (platônica, é preciso destacar) entre um homem "negro" e uma mulher "branca".

Três décadas depois, quando seu compromisso com a literatura se superpõe ao compromisso com a "realidade" - cujo ícone é a relação entre a "morena / mulata" Gabriela e o "árabe" Nacib - vemos Jorge Amado ser aclamado pelo mesmo establishment que rejeitara e criticara no passado. Como dito na introdução, Gabriela, Cravo e Canela foi recebido como porta-voz dos anseios dos desprestigiados, abrindo uma escuta, inclusive, do presidente 
da República e de seus ministros.

Jorge Amado, aparentemente, nunca falou tanto do "real" como quando optou por ser literário e narrativo. Uma narrativa que operou com nossa representação dominante de nação: o desejo erótico entre o (quase) "branco" e estrangeiro colonizador com a voluptuosa e lúbrica "mestiça".

\section{Referências}

ALMEIDA, A. W. B. Jorge Amado: política e literatura. Rio de Janeiro: Campus, 1979.

AMADO, J. Jubiabá. Rio de Janeiro: Record, 1995. Gabriela, Cravo e Canela. São Paulo: Livraria Martins Editora, 1958.

ARAÚJO, R. B. Guerra e paz: Casa-Grande \& Senzala e a obra de Gilberto Freyre nos anos 30. Rio de Janeiro: Editora 34, 1994.

AZEVEDO, A. O Mulato. São Paulo: Ática, 1997. . O Cortiço. São Paulo: Ediouro, s/d (Coleção Prestígio).

FRY, P. O que a Cinderela Negra tem a dizer sobre a "política racial no Brasil". Dossiê Povo Negro - 300 anos, Revista da USP, n. 28, p. 122-135, 1996.

DUMONT, L. Homo hierarquicus: O sistema de castas e sua implicações. Brasília: UnB, 1992.

FREYRE, G. Casa-Grande \& Senzala. Rio de Janeiro: José Olympio, 1977.

MATTA, R. Dona Flor e seus dois maridos: um romance relacional. In: Jorge Amado, Km 70. Tempo Brasileiro, n, 74, p. 3-33, 1983.

Digressão: a fábula das três raças, ou o problema do racismo à brasileira. In: . Relativizando: uma introdução à Antropologia Social. Petrópolis: Vozes, 1981.

MOUTINHO, L. Razão, “Cor" e Desejo: uma análise comparativa sobre relacionamentos afetivo-sexuais 'inter-raciais' no Brasil e na África do Sul. Tese (Doutorado em Antropologia) - PPGAS / IFCS / UFRJ, Rio de Janeiro, 2001. 
Entre o Realismo e o Ficcional: Representações sobre "Raça"...

PRADO, P. Retratos do Brasil: ensaios sobre a tristeza brasileira. Rio de Janeiro: F. Briguiet e Cia., 1931.

SAID, E. Cultura e Imperialismo. São Paulo: Companhia das Letras, 1995.

STOLCKE, V. Racismo y sexualidad en la Cuba colonial. Madrid: Alianza Editorial, 1992.

- Sexo está para gênero, assim como raça para etnicidade? Estudos Afro-Asiáticos, n. 20, p. 101-119, 1991.

STROZEMBERG, I. Gabriela Cravo e Canela ou as confusões de uma cozinheira bem temperada. In: Jorge Amado, Km 70 - Tempo Brasileiro, $\mathrm{n}$. 74, p. 66-93, 1983.

SÜSSEKIND, F. Tal Brasil, qual romance?. Rio de Janeiro: Achiamé, 1984.

\section{NOTAS}

${ }^{1}$ As categorias de "cor" e "raça" estão grifadas com aspas. Sigo, com esse procedimento, a sugestão de Fry (1996). Na percepção do autor, a noção de "raça" e seus termos correlatos devem ser compreendidas como construções locais, históricas e culturalmente determinadas. As aspas, nesse sentido, ajudam a relativizar a "realidade do racismo" como algo homogêneo e transcultural, possibilitando que a analisemos em suas faces mais sutis e/ou menos exploradas.

${ }^{2} \mathrm{O}$ texto que se segue é parte da reflexão que desenvolvi no doutoramento (no prelo). Na tese analisei os valores e as representações sociais sobre "raça", mestiçagem, gênero e erotismo que sustentavam um elo afetivo-sexual entre casais heterossexuais de "raças" diferentes no Brasil e na África do Sul.

${ }^{3}$ Doutora em Antropologia pelo PPGSA / IFCS / UFRJ, professora visitante do Departamento de Políticas e Instituições de Saúde do IMS / UERJ; pesquisadora associada ao Centro Latinoamericano em Sexualidade e Direitos Humanos (CLAM / IMS / UERJ). E-mail: lmoutinho@ims.uerj.br.

${ }^{4}$ Tal acepção nem deve ser compreendida de modo uníssono (há grande disputa em torno dessa idéia), nem tampouco encapsulada como uma definição estática atribuída ao romance, no interior do campo literário. Após a publicação de Capitães da Areia, por exemplo, Jubiabá passou a ser 
interpretado como um "poema" da "gente negra". Em outras palavras, "a poesia de Jubiabá é puxada para o primeiro plano em detrimento de sua classificação, no ano do lançamento, em termos de romance proletário" (ALMEIDA, 1979, p. 139).

${ }^{5}$ Numa reunião, Antônio discursa: “[...] Está contando o que viu na sua vida de malandro. [...] Conta que não gostava de operário, de gente que trabalhava. Mas foi trabalhar por causa do filho. E agora via que os operários se quisessem não seriam escravos...” (ALMEIDA, 1979, p. 283 grifos meus).

6 “" [...] quando a noite chegava [...] ia meter-se e deitava-se ao seu lado, como se para outra coisa não houvesse vivido o dia inteiro. Se entregava toda abandonada nas mãos dele, morrendo em suspiros, gemendo e rindo. No outro dia, quando ele, preso a Gabriela como se ela fosse sua própria vida, queria concretizar os planos do futuro, ela apenas ria, quase a mofar-se dele [...] (ALMEIDA, 1979, p. 114).

7 "No rol das virtudes de Gabriela [...], contavam-se o amor ao trabalho e ao senso de economia. Como arranjava tempo e forças para lavar a roupa, arrumar a casa - tão limpa nunca estivera! cozinhar os tabuleiros para o bar, almoço e jantar para Nacib? Sem falar que a noite estava fresca e descansada, úmida de desejo, não se dando apenas, mas tomando dele, jamais farta, sonolenta ou saciada" (ALMEIDA, 1979, p. 213).

${ }^{8} \mathrm{O}$ arábe Nacib, por exemplo, nascera na Síria e chegara a Ilhéus com quatro anos de idade. Possuía grandes bigodes negros, que lhe conferiam um ar de "sultão destronado" e o (odiado) apelido de turco. Dizia-se brasileiro e ilheense. Havia, de fato, se naturalizado. Mas após o incêndio do cartório, adquiriu novo registro de brasileiro nato. Era, assim, um "enorme brasileiro alto e gordo, cabeça chata e farta cabeleira [com] um ventre demasiadamente crescido" (AMADO, 1958, p. 57), que tinha especial predileção pelas "morenas queimadas na cor". 
Entre o Realismo e o Ficcional: Representações sobre "Raça"...

\section{ABSTRACT}

Between Realism and Fiction: Representations of Race, Sexuality, and Class in Two Paradigmatic Novels by Jorge Amado

This article presents and discusses how concepts and representations of "race", miscegenation, sexuality, gender, erotism, and marriage are operated in two paradigmatic novels by Jorge Amado which represent two important periods in the author's trajectory: Jubiabá, from the period called "proletarian novel", and Gabriela, Cravo e Canela, which marked a twist in Amado's career, beginning of the phase called "dialogical novel". The protagonists in both novels are inter-racial couples who help the author transmit some current social representations (and on science in that time), not only of the relations between blacks and whites, but as well of a nation that, on the one hand, perceives itself as having mixed blood, and, on the other, faced (and faces) the dilemma of racial differentiation. One will see that forbidden desire and class fights lived by the couple black man / white woman (Jubiabá), once contrasted to erotism, marriage, and progress focused by the relation between (almost) white man / woman of mixed blood, explain some current representations of nation transmitted in Brazilian society through its various institutions.

Key words: "Race" / miscegenation; sexuality; class; representations of nation.

Recebido em: 13/09/2004.

Aprovado em: 04/11/2004. 